\title{
How could we realize a win-win strategy on irrigation price policy? Evaluation of a pilot reform project in Hebei Province, China
}

\author{
Jinxia Wang ${ }^{\mathrm{a}, \mathrm{b}, *}$, Lijuan Zhang ${ }^{\mathrm{b}}$, Jikun Huang ${ }^{\mathrm{a}, \mathrm{b}}$ \\ ${ }^{a}$ School of Advanced Agricultural Sciences, Peking University, Beijing 100871, PR China \\ ${ }^{\mathrm{b}}$ Center for Chinese Agricultural Policy at Chinese Academy of Sciences, Institute of Geographical Sciences and Natural Resources Research, Beijing 100101, PR China
}

\section{A R T I C L E I N F O}

\section{Article history:}

Received 3 March 2016

Received in revised form 18 May 2016

Accepted 19 May 2016

Available online 27 May 2016

This manuscript was handled by Geoff

Syme, Editor-in-Chief

\section{Keywords:}

Pilot reform

Groundwater irrigation price

Evaluation

Irrigation application

Benefits and losses

\begin{abstract}
S U M M A R Y
The challenge of increasing irrigation prices while increasing farmers' income exists not only in China but in other countries as well. The overall goal of this paper is to evaluate whether a win-win strategy can be realized in a pilot reform in Hebei, China. The data came from a two-round field survey in 2009 and 2012, which indicated that the key mechanism of the pilot reform was that farmers received similar returns (including reallocated, increased irrigation fees and a government subsidy), but paid different irrigation fees; the difference between the returned money and payment was treated as an incentive for farmers to reduce their use of irrigation. The econometric results showed that in pilot reformed villages, local farmers' groundwater application for irrigating wheat and cotton could decrease by $21 \%$ each. If no subsidies are granted, roughly half of the region's farmers would lose money due to the reform. However, most farmers who receive subsidies were able to earn money in the pilot reformed villages. If several issues are properly resolved (such as selecting more representative villages, increasing the subsidy value, and negatively linking the subsidy with water use), it would be possible for more regions to realize a win-win price reform strategy.
\end{abstract}

(c) 2016 Published by Elsevier B.V.

\section{Introduction}

China's water supply is crucial to its food security. Despite ranking sixth in the world in terms of total water resources, on a per capita basis China only has about a quarter of the world's average supply of potable water (MWR, 2014). Rapidly growing industries and an increasingly wealthy urban population now compete with farmers for limited water resources. As a result, the share of agricultural water use has declined from $97 \%$ in 1949 to $63 \%$ in 2013 (MWR, 2014; Wang et al., 2009). The continued expansion of urbanization will put even greater pressure on agricultural water use and crop production (Yan et al., 2015). Moreover, climate change is expected to aggravate water scarcity in China's major grain-producing regions in the coming decades (Wang et al., 2013). Over the past 50 years, an obvious decline has become evident in the runoff from $60 \%$ of the large rivers in China, and the groundwater table has also decreased significantly in the north (ECSNCCA, 2011).

Faced with the challenge of water scarcity, China's government has begun to promote a very strict system for managing the

* Corresponding author at: No 5, Yiheyuan Road, Haidian District, Beijing 100871, PR China. Tel.: +86 (10) 62765829; fax: +86 (10) 64856533.

E-mail address: jxwang.ccap@pku.edu.cn (J. Wang). country's limited water resources, called the "Three Red Lines" policy. This policy sets clear and binding limits on water usage, efficiency, and quality (Chen, 2009). In early 2012, the State Council announced that the policy would limit total national water use to less than 700 billion $\mathrm{m}^{3}$ per year. This quantity is equal to approximately three quarters of China's total annual exploitable freshwater resources. In addition, the policy is designed to raise irrigation efficiency to $60 \%$ by 2030 . While investment in watersaving technology is necessary for increasing irrigation efficiency, the adoption rate of irrigation technology is low in China (Blanke et al., 2007). Growing evidence indicates that this failure to adopt water-saving technologies is mainly due to a lack of incentives for farmers to increase their irrigation efficiency (Liu et al., 2011; Wang, 2012). Policymakers and scholars are therefore turning their attention to how effective incentive mechanisms could be established through applying economic instruments such as price policies (Dinar and Mody, 2004; Huang et al., 2010).

Although water price reform in the Chinese industrial and domestic sectors has been implemented smoothly in recent years, no obvious progress has been made in the agricultural sector (Wang, 2012). The major concern of policymakers regarding the reform of irrigation prices is that increasing these prices will reduce farmers' income, which is already much lower than that of urban residents. The suspected negative impacts of increasing 
irrigation fees on farmers' income have been confirmed by scholars (Huang et al., 2010). Therefore, irrigation prices are not only part of economic policy, but also a political issue. In fact, with the implementation of the agriculture tax exemption and the grain subsidy policy from 2004, some developed regions in China have even exempted farmers from the collection of irrigation fees to further reduce their financial burden (Wang, 2012). However, if farmers do not need to pay irrigation fees, they have no incentive to reduce their use of water by increasing irrigation efficiency (Dinar and Mody, 2004; Dinar and Saleth, 2005; Huang et al., 2010).

Increasing both irrigation prices and farmers' income is a challenge not just in China but in a number of countries where farmers are used to inexpensive or even free water (Dinar and Saleth, 2005; Hellegers and Perry, 2006). Some scholars assert that farmers are likely to resist a pricing policy for water supply because of the negative impact on their income, particularly when there are few opportunities to recoup the shortfall elsewhere and no visible signs of the water supply improving (see Gomez-Limon and Riesgo, 2004; Mejias et al., 2004). Many studies have verified these perceptions of income decline as a result of price increases. The negative impact of increasing irrigation prices on farmers' income is mainly due to the inelastic demand for irrigation water, as revealed by several studies (see Moore et al., 1994; Ogg and Gollehon, 1989; Schoengold et al., 2006).

Is there an economic solution to this political issue in the real world? Dinar and Mody (2004) found that there is. As raising irrigation water prices may hurt farmers' income, finding a way to persuade them to accept and apply complementary conservation tools during the adjustment period is crucial for reforming irrigation prices (Dinar and Mody, 2004). Based on their empirical study of northern China, Huang et al. (2010) proposed developing a subsidy program in tandem with an irrigation pricing policy that transfers income to households as compensation for farmers' lost income. However, questions remain as to whether these measures can be implemented in the field and how they will impact the use of irrigation and farmers' income. In order to fully understand these issues, the ideal method would be to utilize randomized control trials with a set of specific institutions and policies as treatments in certain places. However, conducting such a study is constrained by many socioeconomic and political difficulties.

Fortunately, the pilot irrigation price reform (namely, the "Increase Price and Provide Subsidy" reform) in Hebei Province, China provided an experiment to help us answer our questions. The reform is supported by the national "Water Saving Society" Project and has been administered by local leaders in Hebei's Taocheng District since 2005. In Taocheng, more than $90 \%$ of irrigation depends on groundwater resources; therefore, the reform focuses on groundwater irrigation prices. In order to win the acceptance and support of farmers, this reform established a mechanism that is expected to realize the win-win goal of reducing water application for irrigation and maintaining or even increasing farmers' income at the same time. Despite attracting a great deal of attention from policymakers and the media, the reform has still not been extended to other regions (WRBTD, 2012). In addition, although local leaders and a few scholars have analyzed the reform, most research has been based on either case studies (e.g., Chang and Liu, 2010; Li, 2009) or theoretical analyses (Chen et al., 2014); few empirical studies have been conducted to assess the reform itself. Due to the limited understanding of the reform, it is difficult to resolve the policymakers' confusion.

The overall goal of this paper is to evaluate the effectiveness of the pilot irrigation price reform in realizing the win-win reform strategy to increase irrigation efficiency and maintain or increase farmers' income. We pursued this goal in the following four stages. First, we examined how the reform was designed and implemented in Taocheng. Second, we evaluated the effectiveness of the reform on groundwater application for irrigating three major crops (wheat, maize, and cotton). Third, we discussed the economic benefits or losses to participating farmers. And fourth, we identified the major issues relevant to the sustainable implementation of the reform and the possibility of extending it to other regions.

The rest of the paper is organized as follows. The second section describes the study region, data sources, and major variables used in the analysis. The third section examines the implementation of the pilot irrigation price reform. The fourth section identifies the impacts of the pilot reform on irrigation practices by crop. The fifth section explores the benefits and costs to farmers who participated in the reform, as well as some of the issues relevant to the sustainable implementation of this reform and its extension. Finally, the sixth section presents the conclusion and some policy implications.

\section{Study region and data}

Taocheng District is located in Hengshui City, Hebei Province, northern China. Its total land area is $592 \mathrm{~km}^{2}$, with a population of 430,000 . The endowment of water resources in Taocheng is extremely limited: the water available per capita is only $1 / 18$ of the national average $\left(2100 \mathrm{~m}^{3}\right)$, which is lower than the average for Hebei Province (1/7 of the national average) (Chen et al., 2014; MWR, 2014). In this region, nearly $90 \%$ of water use (mainly for irrigation) depends on groundwater resources, and more than $70 \%$ of the region's tubewells draw groundwater from deep aquifers (WRBHC, 2012). Due to the increased water demand, groundwater is being overexploited, and as a result the water table is declining by more than $2 \mathrm{~m}$ annually (Chen et al., 2014). Due to the serious water shortage and related environmental problems, the Water Resources Bureau in Hebei selected Taocheng as one of the pilot regions for implementing irrigation price reform in 2005.

In order to understand the implementation and effectiveness of the pilot irrigation price reform, we organized a two-round field survey in Taocheng. The first round was administered in 2009. Based on our communications with Water Affairs Bureau (WAB) officials in Taocheng, we divided the 354 villages in the district into two groups: the first group (52 villages) participated in the pilot reform (pilot group), while the second (the remaining 314 villages) did not (control group). We randomly selected 10 villages from each group in which to conduct face-to-face interviews. From each of these 20 randomly selected villages, 4 farm households were selected, and from each of these households 2 plots were selected for detailed investigation. In total, our sample included 160 plots, 80 farm households, and 20 villages in 2009. In 2012, we administered a second round of the survey, and the same types of information were collected. This round included interviews with many of the same farm households in the same villages, based on the same questionnaires as 2009. However, because 15 of the original farm households were no longer living in the villages, we selected 15 new ones to interview.

We designed two separate survey instruments to collect information in each village: one for farmers and one for village leaders. The first important piece of information we collected was the rate for irrigation fees, including those for both groundwater and surface water irrigation. The groundwater irrigation fee is closely related to the amount of electricity used to pump water, and in this region all tubewells have a meter to measure electricity use for irrigation. The farmers were able to tell us the total volume of electricity used per crop, the total irrigation fee they paid, and the price of the electricity used for irrigation. For those villages that participated in the reform, we asked farmers how much they paid in groundwater irrigation fees before the reform, and how much they 
received in subsidies following the reform. For surface water irrigation, farmers paid by land area and per year. In addition to the irrigation fees, village leaders also collected management fees from farmers for operating and maintaining tubewells and canals. We asked the village leaders about the year the reform began, the rate for irrigation fees paid before and after the reform, management fees, electricity prices, subsidies from the government, when the Water User Associations (WUAs) were established, and how they implemented the reforms in their village.

In addition to the relevant information on irrigation fees, we also collected information on the volume of irrigation applied by crop in each plot. We asked farmers to report the irrigation time, total number of irrigations during the entire growing season, and volume of irrigation applied to each crop. If farmers were not clear about the volume of irrigation applied, we obtained this information from the irrigation manager who oversaw each household's irrigation. The managers were usually able to give us detailed information on both groundwater and surface water irrigation. For groundwater irrigation, based on the information on the size of the tubewell pump and the average volume of water that each pump siphoned per hour, we calculated the volume of groundwater irrigation by multiplying the average volume of groundwater pumped per hour by the irrigation duration. For surface water irrigation, village leaders had records on the total amount of surface water irrigation in the village per time period and total irrigated area. Based on this information, we estimated the average amount of surface water irrigation per area per time period in the village, and multiplied this number by the irrigation time per crop per household to obtain the volume of surface water irrigation per crop per household.

Finally, we collected information on the characteristics of plots, households, and villages. The plot characteristics included soil type, distance from plot to tubewell, and the adoption of irrigation technologies in the field. Household characteristics included the age and education of the household head, off-farm work, and farm size. Of the village characteristics, the most significant information related to the water scarcity situation, such as whether water was scarce or not based on their experience. Statistical descriptions of all the collected information are included in Tables $\mathrm{A}-\mathrm{C}$ in Appendix A.

\section{Implementation of the pilot irrigation price reform}

\subsection{Design of the reform}

With the revision and issuance of the new "Water Law" in 2002, the establishment of a Water Saving Society was formally proposed by China's national government. The purpose of the society is to control the increase in total water use and reduce the pressure of water scarcity. The major measures proposed by the government are the application of a quota management policy, reformation of water pricing, establishment of a water-rights institution, and promotion of water-saving technologies (MWR, 2002). In order to realize the purpose of establishing a Water Saving Society, the Ministry of Water Resources (MWR) issued the regulation "Pilot Guidance for Establishing a Water Saving Society" and encouraged provinces to apply for pilot projects from the MWR. The MWR will allocate funds for implementing these measures for every pilot project it approves.

As one of the regions facing serious water shortages, Hebei Province began implementing pilot projects in 2005. Taocheng District was selected as one of the first three pilot project regions. In the beginning of the pilot project, based on the national government's policies and experience with other such projects, WAB officials in Taocheng tried to implement a water quota management policy and establish a water-rights institution; however, they encountered many difficulties. Village leaders and farmers in particular had few incentives to participate in the reform, and the transaction costs of communication and monitoring were high (Chang and Liu, 2010). Later, based on their field survey and careful consideration, the WAB officials identified one management mechanism and named it "Increase Prices and Provide Subsidies." The general idea of the mechanism is to achieve a win-win policy of increasing groundwater irrigation prices to reduce irrigation while also providing subsidies to farmers to offset the potential negative impacts on their income.

The overall design framework of the "Increase Prices and Provide Subsidies" policy is shown in Fig. 1. As the figure illustrates, groundwater irrigation fees were divided into two parts for farmers who participated in the reform: $(A)$ the irrigation fee before reform and (B) the added irrigation fee due to the reform. Part A is what farmers paid before the reform-the electricity fee that had to be submitted to the power company, and the management fee that had to be submitted to the village management committee. Part B comprised the added irrigation fee due to the reform, which the village leaders were responsible for managing and depositing in the bank. At the end of the year, village leaders withdrew the funds from part B from the bank and reallocated them to the farmers based on land area. The reform subsidy provided by the pilot reform project in Taocheng was added to the part B funds allocated to the farmers.

The key aspect of the reform mechanism was that farmers received similar returns by area (part B and the reform subsidy); however, they paid different irrigation fees because their groundwater use varied by area. The difference between the irrigation fee paid and the return was treated as an incentive for farmers to reduce the amount of water they used to irrigate. If some farmers applied less water per area than others, they also ended up with more money than the others, because they paid a lower irrigation fee but received a similar return per area. In the following few sections, we will explore how the reform was implemented and whether it returned the expected result.

\subsection{Implementation of groundwater irrigation price reform}

\subsubsection{Basic characteristics of sample villages}

The survey results showed that groundwater was the major source of irrigation water at the sample sites, and the average population of the sample villages was 650 . In our sample villages, $77 \%$ of their irrigated land depended only on groundwater, $21 \%$ depended on both groundwater and surface water, and $2 \%$ depended only on surface water. With regard to water for irrigation, there were no significant differences between the villages that participated in the pilot reform project and those that did not.

Deep tubewells are major water supply facilities for groundwater irrigation. On average, there were 8 tubewells and 116 ha of irrigated land per village. Of all the tubewells, $96 \%$ were the deep type, ranging from 200 to $300 \mathrm{~m}$. The remaining shallow tubewells (with an average depth of $60 \mathrm{~m}$ ) were found only in those villages that did not participate in the reform. The primary reasons for depending mainly on deep tubewells are that the shallow aquifer in Taocheng has almost dried up, and groundwater quality is poor due to serious salinity problems. These phenomena also reflect the serious water scarcity in this area. Based on their large field survey of northern China, Wang et al. (2006) found that more than $80 \%$ of tubewells are managed by farmers. However, at our sample sites in Taocheng, nearly all tubewells were managed by village management committees.

In order to implement the pilot reform, the selected villages were required to establish WUAs. However, the managers of these WUAs were village leaders, not farmers. Therefore, in our sample 


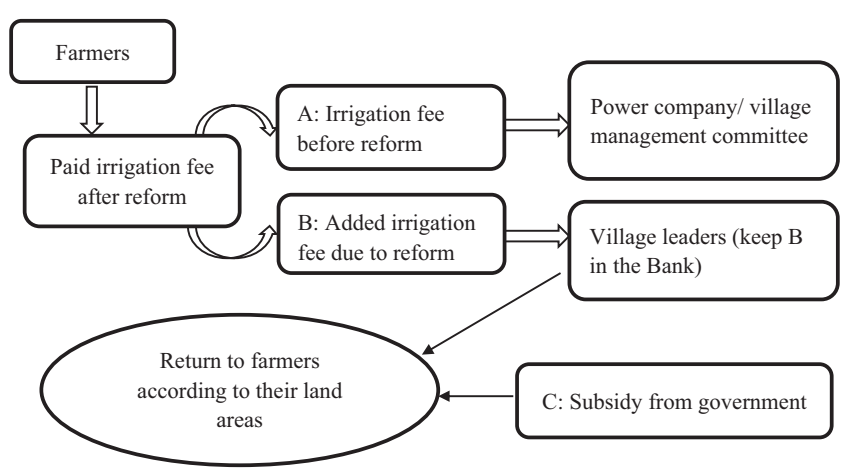

Fig. 1. Mechanism of "Increase Price and Provide Subsidy" pilot reform for groundwater irrigation in Taocheng District in Hebei Province.

villages, village leaders also served as irrigation managers. In some villages, the leaders would hire a few farmers to operate the tubewells and collect the irrigation fees; however, these farmers had no right to participate in making management decisions. As deep tubewells entail high investment and operation costs, it is difficult for individual farmers to invest in and manage them, so these sample villages selected village leaders to act as managers.

\subsubsection{Progress of pilot reform}

Based on the field survey, not all villages implemented the reform measures at the same time. Of the 10 villages that participated in the reform, only 1 implemented the changes in 2005; 3 began in 2006, 3 in 2007, and 3 in 2008. This implies that the reform was pushed gradually, and local WAB officials adopted a step-by-step approach to it after accumulating some experience. Even though they were not rolled out at the same time, the implementation plans in all pilot villages were similar.

It is important to note that not all villages implemented the reform as planned. During the field survey, we collected information on groundwater irrigation fees from both village leaders and farmers. Based on their responses, we found that information on groundwater irrigation fees given by village leaders was consistent with the farmers' responses in 7 of 10 pilot villages; these were defined as pilot reformed villages. However, in the other three villages, information on groundwater irrigation fees differed between village leaders and farmers. On average, the irrigation fees reported by village leaders were $30 \%$ higher than those reported by farmers, who indicated that their irrigation fees were similar to what they had paid before the reform. In other words, although these three villages had received the project subsidies and were classified as pilot villages, the village leaders had not implemented the reform in practice. We therefore defined them as pilot non-reformed villages.

The second round of the field survey revealed that a few villages ceased their implementation of or involvement in the reform during 2009 and 2012 (Table 1). Of the seven pilot reformed villages in 2009, one had switched from the reformed to the non-reformed group; another had switched to the control group. Of the three pilot non-reformed villages in 2009, one had also ceased implementing the reform in 2012, even nominally. Based on our further communication with the villages that had withdrawn from the reform program, almost all of the village leaders reported that participation was too time-consuming.

\subsubsection{Change in irrigation fees and government subsidies}

As shown in Table 2, for those villages that implemented the reform in practice, farmers' irrigation fees increased by more than one-third in nominal terms and about one-fifth in real terms. Before the implementation of the reform, nominal irrigation fees
Table 1

Reform transition during 2009-2012.

\begin{tabular}{cccc}
\hline \multicolumn{3}{c}{ Reform status in 2012} & \\
\cline { 2 - 3 } & Pilot reformed villages & Pilot non-reformed villages & Control villages \\
\hline \multicolumn{2}{c}{ Pilot reformed villages in 2009} & & \\
1 & $\mathrm{Y}$ & & \\
2 & $\mathrm{Y}$ & & \\
3 & $\mathrm{Y}$ & $\mathrm{Y}$ \\
4 & $\mathrm{Y}$ & \\
5 & $\mathrm{Y}$ & $\mathrm{Y}$ & \\
6 & & & \\
7 & & $\mathrm{Y}$ & \\
Pilot & non-reformed villages in 2009 & \\
8 & & $\mathrm{Y}$ & \\
9 & & \\
10 & &
\end{tabular}

Note: "Y" means "Yes".

ranged from 0.65 to 0.75 yuan/kW (an average of 0.69 yuan $/ \mathrm{kW}$ ) (Table 2, column 2). In 2009, all reformed villages increased their irrigation fees by $34 \%$ (column 5) to an average of 0.92 yuan $/ \mathrm{kW}$ (column 3). The average irrigation fee in 2012 was little different from that of 2009, reaching 0.95 yuan $/ \mathrm{kW}$ (column 4); compared to the irrigation level before reform, irrigation fees increased by $38 \%$ (column 6). However, if we examine the change in irrigation fees in real terms, ${ }^{1}$ we find that the reform resulted in increases of irrigation fees by $20 \%$ in 2009 and $15 \%$ in 2012 (Table 3, columns 5 and 6). Another interesting aspect of the increase in irrigation fees is that not all villages increased their fees by the same level: some increased them by more than $40 \%$ and some by less than $10 \%$ in real terms. This reflects the complicated communication between project managers in the WAB and village leaders. In fact, it was expected that even the increased fees would be returned to farmers; however, determining the level of the increase is a sensitive issue.

In order to encourage village leaders and farmers to participate in the reform, the local government provided some subsidies for farmers. In 2009, on average, farmers qualified for the government subsidy if they spent 0.08 yuan $/ \mathrm{kW}$-about $35 \%$ of the increased irrigation fee (Table 2, column 7). Both nominally and in real terms, the government subsidies in 2012 had not obviously changed from 2009 (Tables 1 and 2, column 8). Subsidies differed by village, but there were only two subsidy levels: 0.05 yuan/kW and 0.10 yuan/ $\mathrm{kW}$. The subsidy source for local governments (the WAB) was the pilot project fund. Therefore, if the government had no project funds, there were no other financial sources for the subsidies.

\section{Impact of the pilot reform on groundwater application rate for irrigating major crops}

\subsection{Descriptive statistical analysis}

A descriptive statistical analysis indicated that local farmers in pilot reformed villages may use less groundwater for irrigating wheat than those in other villages. In 2009, villages that put the reform into practice used $2654 \mathrm{~m}^{3} /$ ha groundwater to irrigate wheat, which was less than pilot non-reformed villages that only implemented the reforms nominally $\left(2671 \mathrm{~m}^{3} / \mathrm{ha}\right)$ or control villages that did not participate at all $\left(2816 \mathrm{~m}^{3} / \mathrm{ha}\right.$ ) (Table 4 , column 1). The results from 2012 were similar to those from 2009 (Table 4 , column 2).

Similar to wheat, the groundwater application rate for irrigating cotton was also lower in pilot reformed villages, but it was not so for maize. The results showed that in 2009, in pilot reformed

\footnotetext{
${ }^{1}$ All monetary amounts are inflation adjusted to 2009 currency.
} 
Table 2

Change of irrigation fee for pilot villages in 2009 (nominal price in 2009).

\begin{tabular}{|c|c|c|c|c|c|c|c|c|}
\hline \multirow[t]{3}{*}{ Village code } & \multirow{3}{*}{$\begin{array}{l}\text { Beginning year of implementing the } \\
\text { project (year) }\end{array}$} & \multicolumn{3}{|c|}{ Irrigation fee ${ }^{\mathrm{a}}$ paid by farmers (yuan $/ \mathrm{kW}^{\mathrm{b}}$ ) } & \multirow{2}{*}{\multicolumn{2}{|c|}{$\begin{array}{l}\text { Share of increased irrigation fee due to } \\
\text { reform }(\%)\end{array}$}} & \multirow{2}{*}{\multicolumn{2}{|c|}{$\begin{array}{l}\text { Subsidies } \\
\text { from } \\
\text { government } \\
\text { (yuan } / \mathrm{kW} \text { ) }\end{array}$}} \\
\hline & & \multirow{2}{*}{$\begin{array}{l}\text { Before implementing the } \\
\text { project } \\
\text { (1) }\end{array}$} & \multirow{2}{*}{$\begin{array}{l}2009 \\
(2)\end{array}$} & \multirow{2}{*}{$\begin{array}{l}2012 \\
(3)\end{array}$} & & & & \\
\hline & & & & & {$[(2)-(1)] /(1) * 100$} & {$[(3)-(1)] /(1) * 100$} & $\begin{array}{l}2009 \\
(4)\end{array}$ & $\begin{array}{l}2012 \\
(5)\end{array}$ \\
\hline 1 & 2006 & 0.65 & 0.95 & 0.98 & 46 & 51 & 0.10 & 0.11 \\
\hline 2 & 2007 & 0.65 & 0.95 & 1.00 & 46 & 54 & 0.10 & 0.10 \\
\hline 3 & 2007 & 0.75 & 0.90 & 0.90 & 20 & 20 & 0.05 & 0.05 \\
\hline 4 & 2008 & 0.65 & 0.77 & 0.86 & 18 & 32 & 0.05 & 0.10 \\
\hline 5 & 2008 & 0.74 & 0.9 & 1.00 & 22 & 35 & 0.05 & 0.10 \\
\hline $6^{c}$ & 2005 & 0.68 & 0.98 & - & 44 & - & 0.10 & - \\
\hline \multirow[t]{2}{*}{$7^{\mathrm{d}}$} & 2007 & 0.70 & 0.98 & - & 40 & - & 0.10 & - \\
\hline & Average & 0.69 & 0.92 & 0.95 & 34 & 38 & 0.08 & 0.09 \\
\hline
\end{tabular}

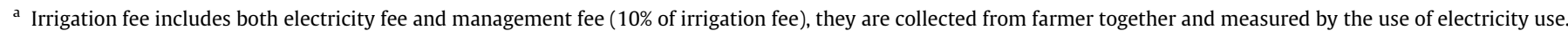

b KW indicates the unit of electricity, kilowatt.

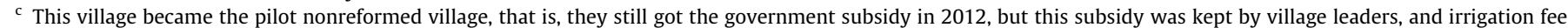
collected from farmers in 2012 (0.81 yuan/kW, nominal term) was also much less than that in 2009 .

${ }^{d}$ This village became the control village; that is, they did not get government subsidy in 2012 . The irrigation fee collected from farmers in 2012 was 0.78 yuan/ $\mathrm{kW}^{\mathrm{b}}$ (nominal term).

Table 3

Change of irrigation fee for pilot reformed villages in 2009 (real price in $2009^{\mathrm{e}}$ ).

\begin{tabular}{|c|c|c|c|c|c|c|c|c|}
\hline \multirow[t]{3}{*}{ Village code } & \multirow{3}{*}{$\begin{array}{l}\text { Beginning year of implementing the } \\
\text { project (year) }\end{array}$} & \multicolumn{3}{|c|}{ Irrigation fee ${ }^{\mathrm{a}}$ paid by farmers (yuan/kW $\mathrm{kW}^{\mathrm{b}}$ ) } & \multirow{2}{*}{\multicolumn{2}{|c|}{$\begin{array}{l}\text { Share of increased irrigation fee due to } \\
\text { reform (\%) }\end{array}$}} & \multirow{2}{*}{\multicolumn{2}{|c|}{$\begin{array}{l}\text { Subsidies } \\
\text { from } \\
\text { government } \\
\text { (yuan } / \mathrm{kW} \text { ) }\end{array}$}} \\
\hline & & \multirow{2}{*}{$\begin{array}{l}\text { Before implementing the } \\
\text { project } \\
\text { (1) }\end{array}$} & \multirow{2}{*}{$\begin{array}{l}2009 \\
(2)\end{array}$} & \multirow{2}{*}{$\begin{array}{l}2012 \\
(3)\end{array}$} & & & & \\
\hline & & & & & {$[(2)-(1)] /(1) * 100$} & {$[(3)-(1)] /(1) * 100$} & $\begin{array}{l}2009 \\
(4)\end{array}$ & $\begin{array}{l}2012 \\
(5)\end{array}$ \\
\hline 1 & 2006 & 0.74 & 0.95 & 0.90 & 29 & 22 & 0.10 & 0.10 \\
\hline 2 & 2007 & 0.73 & 0.95 & 0.91 & 31 & 25 & 0.10 & 0.09 \\
\hline 3 & 2007 & 0.84 & 0.90 & 0.82 & 7 & -2 & 0.05 & 0.05 \\
\hline 4 & 2008 & 0.69 & 0.77 & 0.78 & 12 & 13 & 0.05 & 0.09 \\
\hline 5 & 2008 & 0.79 & 0.90 & 0.91 & 15 & 16 & 0.05 & 0.09 \\
\hline $6^{c}$ & 2005 & 0.68 & 0.98 & - & 44 & - & 0.1 & - \\
\hline \multirow[t]{2}{*}{$7^{d}$} & 2007 & 0.70 & 0.98 & - & 40 & - & 0.1 & - \\
\hline & Average & 0.76 & 0.92 & 0.86 & 20 & 15 & 0.08 & 0.08 \\
\hline
\end{tabular}

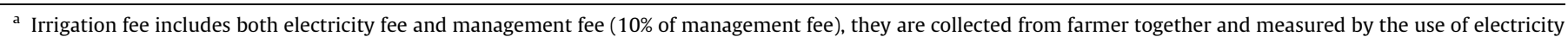
use.

${ }^{\mathrm{b}} \mathrm{KW}$ indicates the unit of electricity, kilowatt.

c This village became the pilot nonreformed village, that is, they still got the government subsidy in 2012, but this subsidy was kept by village leaders, and irrigation fee collected from farmers in 2012 ( 0.74 yuan/kW, real term) was also much less than that in 2009.

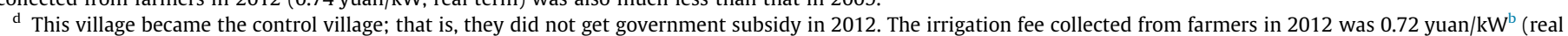
term).

e Both irrigation fee and government subsidy are inflation adjusted to the price level in 2009 by using rural consumption price index.

Table 4

Application rate of groundwater irrigation for three crops $\left(\mathrm{m}^{3} / \mathrm{ha}\right)$.

\begin{tabular}{lrr}
\hline & 2009 & 2012 \\
\hline Wheat & & \\
$\quad$ Pilot reformed villages & 2654 & 2549 \\
Pilot non-reformed villages & 2671 & 2799 \\
Control villages & 2816 & 2953 \\
Maize & & \\
Pilot reformed villages & 1291 & 1697 \\
Pilot non-formed villages & 960 & 1403 \\
Control villages & 1130 & 1692 \\
Cotton & & \\
Pilot reformed villages & 1137 & 897 \\
Pilot non-reformed villages & 1557 & 1170 \\
Control villages & 1139 & 1103 \\
\hline
\end{tabular}

villages, the groundwater application for irrigating cotton was $1137 \mathrm{~m}^{3} /$ ha, which is lower than that in both pilot non-reformed villages ( $\left.1557 \mathrm{~m}^{3} / \mathrm{ha}\right)$ and control villages $\left(1139 \mathrm{~m}^{3} / \mathrm{ha}\right.$ ) (Table 4 , column 1). The results for 2012 were similar to those from 2009
(Table 4, column 2); however, if we examine the groundwater irrigation of maize, we do not find similar results. To determine whether the groundwater application rate for wheat and cotton is more sensitive to irrigation prices than maize, we need to further examine it using econometric analysis and controlling for the effects of other factors.

\subsection{Specification of econometric models}

In addition to irrigation prices, other socioeconomic and physical factors also influence farmers' decisions regarding irrigation. In order to measure the influence of the reform on farmers' choices in this regard, we established the following econometric models based on our two-round field survey in Taocheng:

$$
\begin{aligned}
& W_{c i j k}=\alpha_{1}+\beta_{1} R_{k}+\beta_{3} Z_{c i j k}+\beta_{4} D_{k}+\beta_{5} T_{k}+\varepsilon_{c i j k} \\
& W_{c i j k}=\alpha_{2}+\eta_{1} R_{k}+\eta_{2} N_{k}+\eta_{3} Z_{c i j k}+\eta_{4} D_{k}+\eta_{5} T_{k}+\Phi_{c i j k} \\
& W_{c i j k}=\alpha_{3}+\gamma_{1} P_{c i j k}+\gamma_{2} Z_{c i j k}+\gamma_{3} D_{k}+\gamma_{4} T_{k}+\delta_{c i j k}
\end{aligned}
$$


In the above three models, the subscript $c$ indicates the crop (wheat, maize, or cotton), $i$ indicates the plot, $j$ indicates the household, and $k$ indicates the village. The dependent variable $W_{c i j k}$ represents the volume of groundwater irrigation per area $\left(\mathrm{m}^{3} / \mathrm{ha}\right)$ by crop on the ith plot of $j$ th household in $k$ th village. In the estimations, we transferred $W_{\text {cijk }}$ to be in log form.

The key independent variables we are interested are $R_{k}$ in model (1) and $N_{k}$ in model (2). $R_{k}$ is a dummy variable that measures whether a village is a pilot reformed village $\left(1=\right.$ yes; $0=$ no). $N_{k}$ is also a dummy variable, measuring whether a village is a pilot non-reformed village $(1=$ yes; $0=$ no). Model (1) compares irrigation in pilot reformed villages and those villages that were not (either pilot non-reformed or control villages). Model (2) compares irrigation in pilot reformed villages with control villages, and non-reformed villages with control villages. Because the reform increased irrigation fees, it thereby directly influenced farmers' irrigation behavior. Therefore, in Model (3), instead of using reform variables $\left(R_{k}\right.$ and $\left.N_{k}\right)$, we used variable $P_{c i j k}$ (the change in irrigation fees in real terms, as compared to that prior to implementation) to measure the impacts of the reform on groundwater irrigation.

We also incorporated one set of control variables $\left(Z_{c i j k}\right)$ in all three models. These included: (i) a village-level variable: whether there is a water shortage in the village ( $1=$ yes; $0=$ no); (ii) household-level variables: age and education of household head (year), share of off-farm work, and farm size (ha); and (iii) plotlevel variables: volume of surface water irrigation per area $\left(\mathrm{m}^{2}\right.$ per ha), loam soil $(1=$ yes; $0=$ no), clay soil $(1=$ yes; $0=$ no), distance from plot to tubewell $(\mathrm{km})$, share of land using ground pipes, and share of land using surface pipes. In order to control for factors that do not vary over time, we added township dummy variables $\left(D_{k}\right)$ in the three models. As we had data for two years (2009 and 2012 ), we also added a year dummy variable $\left(T_{k}\right)$ to control for factors that vary over time $(1=2012 ; 0=2009)$. The parameters to be estimated are $\alpha_{1}-\alpha_{3}, \beta_{1}-\beta_{5}, \eta_{1}-\eta_{5}$ and $\gamma_{1}-\gamma_{4}$, and $\varepsilon_{c i j k}, \Phi_{c i j k}$, $\delta_{c i j k}$ are random error terms that assume no relationship with other independent variables.

We used Ordinary Least Square (OLS) estimation to run the regressions (models $1-3$ ). The OLS estimator is consistent when the regressors are exogenous and there is no perfect multicollinearity, and optimal in the class of linear unbiased estimators when the errors are homoscedastic and serially uncorrelated. Under these conditions, OLS provides minimum-variance meanunbiased estimation when the errors have finite variances. Since our dependent variable was one continuous variable, the independent variables in the regressions were exogenous ${ }^{2}$ and had no serious multicollinearity, and the error terms were also homoscedastic and uncorrelated, it was rational for us to use OLS. More detailed information on OLS can be found in many econometric texts, such as Wooldridge (2002).

\subsection{Estimation results of the econometric models}

The estimation results for models 1-3 using the survey data are presented in Tables 4-6; they all performed well. The adjusted $R^{2} \mathrm{~s}$ were about 0.30 for the wheat models; about 0.25 for maize; and

\footnotetext{
2 Before implementing the reform, WAB officials will determine which villages are potential pilot sites. The selection principle is based on their experience of whether the village leaders would like to cooperate. After that, WAB officials will talk with village leaders and then the final sample sites will be decided. Therefore, the first step for selecting pilot villages is mainly decided by WAB officials, not village leaders. Therefore, the sample selection problem is not that serious. In addition, our regression data is at the plot level and the reform variable is at the village level; farmers in the pilot reformed villages have no right to decide whether they will participate in the reform or not, as the decision is made by the village leaders. Therefore, for individual farmers, this reform variable can be treated as an exogenous one.
}

Table 5

Regression results of the determinants of irrigation application rate of groundwater for wheat.

\begin{tabular}{|c|c|c|c|}
\hline & \multicolumn{3}{|c|}{$\begin{array}{l}\text { Irrigation application rate of } \\
\text { groundwater }\left(\mathrm{m}^{3} / \mathrm{ha}\right)(\mathrm{log})\end{array}$} \\
\hline & (1) & $(2)$ & (3) \\
\hline $\begin{array}{l}\text { Pilot reformed villages } \\
(1=\text { yes; } 0=\text { no })\end{array}$ & $\begin{array}{l}-0.2086^{*} \\
(1.70)\end{array}$ & $\begin{array}{l}-0.2385^{*} \\
(1.76)\end{array}$ & \\
\hline $\begin{array}{l}\text { Pilot non-reformed villages } \\
(1=\text { yes; } 0=\text { no })\end{array}$ & & $\begin{array}{l}-0.1468 \\
(0.80)\end{array}$ & \\
\hline $\begin{array}{l}\text { Change of groundwater irrigation } \\
\text { fee (yuan } / \mathrm{kW})\end{array}$ & & & $\begin{array}{l}-0.7007^{*} \\
(1.98)\end{array}$ \\
\hline $\begin{array}{l}\text { Whether water is scarce ( } 1=\text { yes; } \\
\qquad 0=\text { no) }\end{array}$ & $\begin{array}{l}-0.0654 \\
(0.56)\end{array}$ & $\begin{array}{l}-0.0941 \\
(0.71)\end{array}$ & $\begin{array}{l}-0.0492 \\
(0.40)\end{array}$ \\
\hline Age of household head (years) & $\begin{array}{l}-0.0008 \\
(0.12)\end{array}$ & $\begin{array}{l}-0.0004 \\
(0.06)\end{array}$ & $\begin{array}{l}-0.0011 \\
(0.18)\end{array}$ \\
\hline Education of household head (years) & $\begin{array}{l}-0.0061 \\
(0.33)\end{array}$ & $\begin{array}{l}-0.0044 \\
(0.24)\end{array}$ & $\begin{array}{l}-0.0055 \\
(0.30)\end{array}$ \\
\hline Share of off-farm labors & $\begin{array}{l}-0.0899 \\
(0.35)\end{array}$ & $\begin{array}{l}-0.0640 \\
(0.25)\end{array}$ & $\begin{array}{l}-0.1479 \\
(0.53)\end{array}$ \\
\hline Farm size (ha) & $\begin{array}{l}-0.6309 \\
(1.48)\end{array}$ & $\begin{array}{l}-0.5244 \\
(1.31)\end{array}$ & $\begin{array}{l}-0.4970 \\
(1.11)\end{array}$ \\
\hline $\begin{array}{l}\text { Irrigation application rate of surface } \\
\text { water }\left(\mathrm{m}^{3} / \mathrm{ha}\right)\end{array}$ & $\begin{array}{l}-0.0002^{* * *} \\
(3.67)\end{array}$ & $\begin{array}{l}-0.0002^{* * *} \\
(3.86)\end{array}$ & $\begin{array}{l}-0.0002^{* * *} \\
(3.19)\end{array}$ \\
\hline Loam land $(1=$ yes; $0=$ no $)$ & $\begin{array}{l}0.1777^{*} \\
(1.92)\end{array}$ & $\begin{array}{l}0.1569 \\
(1.71)\end{array}$ & $\begin{array}{l}0.1696^{*} \\
(1.86)\end{array}$ \\
\hline Clay land $(1=$ yes; $0=$ no $)$ & $\begin{array}{l}0.1841 \\
(1.36)\end{array}$ & $\begin{array}{l}0.1734 \\
(1.27)\end{array}$ & $\begin{array}{l}0.1764 \\
(1.35)\end{array}$ \\
\hline Distance from plot to tubewell $(\mathrm{km})$ & $\begin{array}{l}0.0900 \\
(0.37)\end{array}$ & $\begin{array}{l}0.0666 \\
(0.27)\end{array}$ & $\begin{array}{l}0.1311 \\
(0.55)\end{array}$ \\
\hline Share of ground pipe & $\begin{array}{l}0.0810 \\
(0.41)\end{array}$ & $\begin{array}{l}0.0853 \\
(0.43)\end{array}$ & $\begin{array}{l}0.1341 \\
(0.75)\end{array}$ \\
\hline Share of surface pipe & $\begin{array}{l}-0.1409 \\
(0.55)\end{array}$ & $\begin{array}{l}-0.1560 \\
(0.61)\end{array}$ & $\begin{array}{l}-0.0898 \\
(0.36)\end{array}$ \\
\hline Township dummy variables & $\begin{array}{l}\text { Not } \\
\text { reported }\end{array}$ & $\begin{array}{l}\text { Not } \\
\text { reported }\end{array}$ & $\begin{array}{l}\text { Not } \\
\text { reported }\end{array}$ \\
\hline Year dummy $(1=2012 ; 0=2009)$ & $\begin{array}{l}-0.0150 \\
(0.14)\end{array}$ & $\begin{array}{l}-0.0196 \\
(0.18)\end{array}$ & $\begin{array}{l}-0.0370 \\
(0.31)\end{array}$ \\
\hline Constant & $\begin{array}{l}8.0979^{* * *} \\
(21.35)\end{array}$ & $\begin{array}{l}8.0945^{* * *} \\
(21.13)\end{array}$ & $\begin{array}{l}8.0332^{* * *} \\
(20.73)\end{array}$ \\
\hline Samples size & 161 & 161 & 161 \\
\hline Adj $R$-squared & 0.2960 & 0.3036 & 0.2922 \\
\hline
\end{tabular}

Note: Absolute value of $t$ statistic in parentheses (cluster standard error at the village level).

${ }^{* *}$ Statistically significant at $5 \%$.

Statistically significant at $10 \%$.

**** Statistically significant at $1 \%$.

about 0.21 for cotton. These values are high enough for a multivariate analysis based on one field survey in a similar region. Regarding the control variables, only a few were statistically significant, possibly indicating that farmers' irrigation behavior is mainly influenced by the irrigation fee. Although there were few statistically significant control variables, we still had some interesting results. For example, in the wheat models, the sign of the use of surface water for irrigation was negative and statistically significant (Table 5). This implies that, after keeping all other factors constant, if farmers can access surface water for irrigation, they will reduce their groundwater application rate.

It is important to note that the estimation results show that implementing reform could significantly reduce the groundwater application rate for irrigating wheat. The coefficient of the variable measuring whether pilot reformed villages was negative and statistically significant in the wheat models (Table 5, row 1). Hence, after keeping the other factors constant, farmers' groundwater application rate for wheat in the pilot reformed villages was significantly lower than that of pilot non-reformed or control villages (column 1). Specifically, if a village implemented the reform, the local farmers' groundwater application rate for wheat decreased by $21 \%$. The coefficient for whether a village was a non-reformed village was not statistically significant (column 2), which implies 
Table 6

Regression results of the determinants of irrigation application rate of groundwater for maize.

\begin{tabular}{|c|c|c|c|}
\hline & \multicolumn{3}{|c|}{$\begin{array}{l}\text { Irrigation application rate of } \\
\text { groundwater }\left(\mathrm{m}^{3} / \mathrm{ha}\right)(\mathrm{log})\end{array}$} \\
\hline & $(1)$ & $(2)$ & $(3)$ \\
\hline Pilot reformed villages & 0.1000 & 0.0915 & \\
\hline$(1=$ yes; $0=$ no $)$ & $(0.92)$ & $(0.83)$ & \\
\hline $\begin{array}{l}\text { Pilot non-reformed villages } \\
(1=\text { yes; } 0=\text { no })\end{array}$ & & $\begin{array}{l}-0.0418 \\
(0.28)\end{array}$ & \\
\hline $\begin{array}{l}\text { Change of groundwater irrigation fee } \\
\text { (yuan } / \mathrm{kW})\end{array}$ & & & $\begin{array}{l}0.1594 \\
(0.57)\end{array}$ \\
\hline $\begin{array}{l}\text { Irrigation application rate of surface } \\
\text { water }\left(\mathrm{m}^{3} / \mathrm{ha}\right)\left(\mathrm{m}^{3} / \mathrm{ha}\right)\end{array}$ & $\begin{array}{l}0.0004^{*} \\
(1.93)\end{array}$ & $\begin{array}{l}0.0004^{*} \\
(1.93)\end{array}$ & $\begin{array}{l}0.0004 \\
(1.90)\end{array}$ \\
\hline Whether water is scarce $(1=$ yes; $0=$ no $)$ & $\begin{array}{l}0.1867^{*} \\
(1.87)\end{array}$ & $\begin{array}{l}0.1775^{*} \\
(1.90)\end{array}$ & $\begin{array}{l}0.1841^{*} \\
(1.90)\end{array}$ \\
\hline Age of household head (years) & $\begin{array}{l}-0.0044 \\
(1.12)\end{array}$ & $\begin{array}{l}-0.0043 \\
(1.08)\end{array}$ & $\begin{array}{l}-0.0041 \\
(1.05)\end{array}$ \\
\hline Education of household head (years) & $\begin{array}{l}-0.0269 \\
(1.90)\end{array}$ & $\begin{array}{l}-0.0267^{*} \\
(1.89)\end{array}$ & $\begin{array}{l}-0.0271^{*} \\
(1.82)\end{array}$ \\
\hline Share of off-farm labors & $\begin{array}{l}-0.3258 \\
(1.28)\end{array}$ & $\begin{array}{l}-0.3204 \\
(1.28)\end{array}$ & $\begin{array}{l}-0.3009 \\
(1.27)\end{array}$ \\
\hline Farm size (ha) & $\begin{array}{l}-0.5205 \\
(1.15)\end{array}$ & $\begin{array}{l}-0.4816 \\
(1.00)\end{array}$ & $\begin{array}{l}-0.5136 \\
(1.13)\end{array}$ \\
\hline $\begin{array}{l}\text { Irrigation application rate of surface } \\
\text { water }\left(\mathrm{m}^{3} / \mathrm{ha}\right)\left(\mathrm{m}^{3} / \mathrm{ha}\right)\end{array}$ & $\begin{array}{l}0.0693 \\
(0.71)\end{array}$ & $\begin{array}{l}0.0610 \\
(0.63)\end{array}$ & $\begin{array}{l}0.0853 \\
(0.82)\end{array}$ \\
\hline Loam land $(1=$ yes; $0=$ no $)$ & $\begin{array}{l}0.0897 \\
(0.66)\end{array}$ & $\begin{array}{l}0.0834 \\
(0.63)\end{array}$ & $\begin{array}{l}0.1134 \\
(0.73)\end{array}$ \\
\hline Clay land $(1=$ yes; $0=$ no $)$ & $\begin{array}{l}0.2888^{* * *} \\
(2.14)\end{array}$ & $\begin{array}{l}0.2820^{*} \\
(1.91)\end{array}$ & $\begin{array}{l}0.2785^{* *} \\
(2.12)\end{array}$ \\
\hline Distance from plot to tubewell $(\mathrm{km})$ & $\begin{array}{l}-0.0269^{*} \\
(1.90)\end{array}$ & $\begin{array}{l}-0.0267^{*} \\
(1.89)\end{array}$ & $\begin{array}{l}-0.0271^{*} \\
(1.82)\end{array}$ \\
\hline Share of ground pipe & $\begin{array}{l}-0.1822 \\
(0.62)\end{array}$ & $\begin{array}{l}-0.1764 \\
(0.59)\end{array}$ & $\begin{array}{l}-0.1846 \\
(0.61)\end{array}$ \\
\hline Share of surface pipe & $\begin{array}{l}-0.1483 \\
(0.42)\end{array}$ & $\begin{array}{l}-0.1468 \\
(0.41)\end{array}$ & $\begin{array}{l}-0.1537 \\
(0.43)\end{array}$ \\
\hline Township dummy variables & $\begin{array}{l}\text { Not } \\
\text { reported }\end{array}$ & $\begin{array}{l}\text { Not } \\
\text { reported }\end{array}$ & $\begin{array}{l}\text { Not } \\
\text { reported }\end{array}$ \\
\hline Year dummy $(1=2012 ; 0=2009)$ & $\begin{array}{l}0.4175^{* * * *} \\
(3.20)\end{array}$ & $\begin{array}{l}0.4171^{* * * *} \\
(3.16)\end{array}$ & $\begin{array}{l}0.4130^{* * *} \\
(3.09)\end{array}$ \\
\hline Constant & $\begin{array}{l}7.4486^{* * *} \\
(14.75)\end{array}$ & $\begin{array}{l}7.4460^{* * *} \\
(14.70)\end{array}$ & $\begin{array}{l}7.4430 \\
(14.50)\end{array}$ \\
\hline Samples size & 182 & 182 & 182 \\
\hline Adj $R$-squared & 0.2534 & 0.2539 & 0.2486 \\
\hline
\end{tabular}

Note: Absolute value of $\mathrm{t}$ statistic in parentheses (cluster standard error at the village level).

* Statistically significant at $10 \%$.

** Statistically significant at $5 \%$.

*** Statistically significant at $1 \%$.

that the groundwater application rate in the pilot non-reformed villages was no different from that in the control ones.

Similar to wheat, implementing reform also significantly reduced the groundwater application rate for cotton, but had no significant impact on maize. In the cotton model, the coefficient of the variable measuring whether a village was a pilot reformed village was negative and statistically significant (Table 7 , row 1 ). This implies that after keeping the other factors constant and comparing them with pilot non-reformed or control villages, in pilot reformed villages local farmers were able to significantly reduce their groundwater application rate for cotton (by 21\%) (column 1). In addition, the groundwater application rate for cotton in pilot non-reformed villages was also not significantly different from that in control ones (column 2). However, even in those that implemented the reform, the groundwater application rate for maize did not significantly change (Table 6 , row 1 ), possibly because maize grows mainly in the rainy season and thus does not need as much irrigation.

\footnotetext{
${ }^{3}$ What is discussed here is one of the possible main reasons observed in our field survey. In the future, we will need more evidence to understand this.
}

Table 7

Regression results of the determinants of irrigation application rate of groundwater for cotton.

\begin{tabular}{|c|c|c|c|}
\hline & \multicolumn{3}{|c|}{$\begin{array}{l}\text { Irrigation application rate of } \\
\text { groundwater }\left(\mathrm{m}^{3} / \mathrm{ha}\right)(\mathrm{log})\end{array}$} \\
\hline & (1) & $(2)$ & (3) \\
\hline $\begin{array}{l}\text { Pilot reformed villages } \\
(1=\text { yes; } 0=\text { no })\end{array}$ & $\begin{array}{l}-0.2131^{*} \\
(1.78)\end{array}$ & $\begin{array}{l}-0.2022^{*} \\
(1.75)\end{array}$ & \\
\hline $\begin{array}{l}\text { Pilot non-reformed villages } \\
(1=\text { yes; } 0=\text { no })\end{array}$ & & $\begin{array}{l}0.1267 \\
(1.14)\end{array}$ & \\
\hline Change of water price (yuan/degree) & & & $\begin{array}{l}-0.8804^{* * *} \\
(3.06)\end{array}$ \\
\hline $\begin{array}{l}\text { Irrigation application rate of surface } \\
\text { water }\left(\mathrm{m}^{3} / \mathrm{ha}\right)\end{array}$ & $\begin{array}{l}0.0000 \\
(0.45)\end{array}$ & $\begin{array}{l}0.0000 \\
(0.60)\end{array}$ & $\begin{array}{l}0.0001 \\
(0.85)\end{array}$ \\
\hline $\begin{array}{l}\text { Whether water is scarce ( } 1 \text { = yes; } \\
\quad 0=\text { no) }\end{array}$ & $\begin{array}{l}-0.1006 \\
(1.25)\end{array}$ & $\begin{array}{l}-0.0752 \\
(0.94)\end{array}$ & $\begin{array}{l}-0.0874 \\
(1.07)\end{array}$ \\
\hline Age of household head (years) & $\begin{array}{l}-0.0025 \\
(0.60)\end{array}$ & $\begin{array}{l}-0.0026 \\
(0.64)\end{array}$ & $\begin{array}{l}-0.0011 \\
(0.23)\end{array}$ \\
\hline Education of household head (years) & $\begin{array}{l}-0.0031 \\
(0.19)\end{array}$ & $\begin{array}{l}0.0004 \\
(0.02)\end{array}$ & $\begin{array}{l}-0.0024 \\
(0.13)\end{array}$ \\
\hline Share of off-farm labors & $\begin{array}{l}0.1551 \\
(0.95)\end{array}$ & $\begin{array}{l}0.1344 \\
(0.79)\end{array}$ & $\begin{array}{l}0.1422 \\
(0.76)\end{array}$ \\
\hline $\begin{array}{l}\text { Irrigation application rate of surface } \\
\text { water }\left(\mathrm{m}^{3} / \mathrm{ha}\right)\end{array}$ & $\begin{array}{l}0.4042 \\
(1.03)\end{array}$ & $\begin{array}{l}0.3859 \\
(1.00)\end{array}$ & $\begin{array}{l}0.4753 \\
(1.19)\end{array}$ \\
\hline Farm size (ha) & $\begin{array}{l}-0.1117 \\
(1.48)\end{array}$ & $\begin{array}{l}-0.0626 \\
(0.76)\end{array}$ & $\begin{array}{l}-0.1167 \\
(1.33)\end{array}$ \\
\hline Loam land $(1=$ yes; $0=$ no $)$ & $\begin{array}{l}0.0591 \\
(0.57)\end{array}$ & $\begin{array}{l}0.0992 \\
(1.03)\end{array}$ & $\begin{array}{l}0.0583 \\
(0.51)\end{array}$ \\
\hline Clay land $(1=$ yes; $0=$ no $)$ & $\begin{array}{l}0.1022 \\
(1.55)\end{array}$ & $\begin{array}{l}0.1004 \\
(1.44)\end{array}$ & $\begin{array}{l}0.1030 \\
(1.50)\end{array}$ \\
\hline Distance from plot to tubewell (km) & $\begin{array}{l}-0.0031 \\
(0.19)\end{array}$ & $\begin{array}{l}0.0004 \\
(0.02)\end{array}$ & $\begin{array}{l}-0.0024 \\
(0.13)\end{array}$ \\
\hline Share of ground pipe & $\begin{array}{l}-0.0036 \\
(0.03)\end{array}$ & $\begin{array}{l}-0.0383 \\
(0.30)\end{array}$ & $\begin{array}{l}-0.0209 \\
(0.16)\end{array}$ \\
\hline Share of surface pipe & $\begin{array}{l}-0.2421^{*} \\
(1.86)\end{array}$ & $\begin{array}{l}-0.2566^{*} \\
(1.92)\end{array}$ & $\begin{array}{l}-0.2611^{*} \\
(1.98)\end{array}$ \\
\hline Township dummy variables & $\begin{array}{l}\text { Not } \\
\text { reported }\end{array}$ & $\begin{array}{l}\text { Not } \\
\text { reported }\end{array}$ & $\begin{array}{l}\text { Not } \\
\text { reported }\end{array}$ \\
\hline Year dummy $(1=2012 ; 0=2009)$ & $\begin{array}{l}-0.0823 \\
(0.80)\end{array}$ & $\begin{array}{l}-0.0889 \\
(0.88)\end{array}$ & $\begin{array}{l}-0.0835 \\
(0.79)\end{array}$ \\
\hline Constant & $\begin{array}{l}7.2163^{\text {**** }} \\
(20.44)\end{array}$ & $\begin{array}{l}7.1836^{* * *} \\
(19.68)\end{array}$ & $\begin{array}{l}7.1320^{* * * *} \\
(17.88)\end{array}$ \\
\hline Samples size & 85 & 85 & 85 \\
\hline Adj $R$-squared & 0.2042 & 0.2158 & 0.2135 \\
\hline
\end{tabular}

Note: Absolute value of $\mathrm{t}$ statistic in parentheses (cluster standard error at the village level).

** Statistically significant at $5 \%$.

* Statistically significant at $10 \%$

**** Statistically significant at $1 \%$.

Finally, as expected and consistent with the above results, increasing the irrigation fees for groundwater significantly reduced its application rate in irrigating wheat and cotton. The coefficients of the variable representing the change in the groundwater irrigation fee were negative and statistically significant in both the wheat and cotton models (Tables 4 and 6, row 3). The results indicated that if the groundwater irrigation fee increased by 1 yuan/ $\mathrm{kW}$ (an increase of approximately 100\% over the present irrigation fee), the groundwater application rate could be reduced by $50 \%{ }^{4}$ for wheat or $59 \%^{5}$ for cotton. Therefore, applying an irrigation price policy is an effective measure for reducing groundwater's application for irrigation. However, it is evident in the estimation results that the irrigation price's elasticity is not high; as the government obviously wants to reduce groundwater use for irrigation, its price must be raised significantly, as other literature has also indicated (Huang et al., 2010). If the price of groundwater for irrigation is raised, it would obviously be better to provide subsidies for farmers in order

\footnotetext{
$450 \%=100 *\left(\exp ^{0.770}-1\right), 0.7007$ is the coefficient of the groundwater irrigation fee in Table 4 (row 3 ).

$559 \%=100 *\left(\exp ^{0.8804}-1\right), 0.8804$ is the coefficient of the groundwater irrigation fee in Table 6 (row 3 )
} 
to offset the negative impacts of the price hike on their income. For this pilot project, the questions are whether farmers' income can really be offset by subsidies, how many farmers will benefit, and how many will lose money. These questions will be discussed in the following section.

\section{Benefits and losses for farmers, and some issues relevant to the extension of the reform}

\subsection{Benefits and losses to farmers due to reform}

The analysis results indicated that if no subsidy is granted, about half of the farmers would lose money due to the reform. As shown in Fig. 2(a), ${ }^{6}$ if no subsidy had been granted, $42 \%$ of wheat farmers would have lost money and $58 \%$ of farmers would have earned money in $2009 .^{7}$ In $2012,50 \%$ of farmers would have lost money and $50 \%$ would have earned more (Fig. 2c). Examining this issue at the village level, if no subsidy had been granted, the total value of lost or earned money was almost zero in 2009 and 2012. It is not hard to understand this, as a subsidy would have reallocated the extra money that some farmers earned to those who lost money. That is, farmers who used more groundwater for irrigation per area were punished, but those who used less were rewarded. This is the purpose of the reform; hopefully it will encourage farmers to use less water for irrigation by comparing their practices with those of other farmers in the village. Similar results were found for maize and cotton farmers ((a) and (c) in Fig. 2; (a) and (c) in Fig. 3).

However, most farmers could earn money in villages where the reform is implemented if they received a subsidy. In order to encourage farmers to support and participate in the reform, local governments provided some subsidies to them in the pilot reformed villages. Obviously, the subsidies provided offset the negative impacts of the reform on farmers' income, as only $11 \%$ of wheat farmers lost money in 2009, and only 5\% in 2012, after receiving a subsidy ((b) and (d) in Fig. 2). We also found similar results for both maize and cotton farmers: relatively few of them lost money after they received a subsidy ((b) and (d) in Fig. 3; (b) and (d) in Fig. 4). On average, wheat farmers earned 126 yuan per ha in 2009 and 204 yuan per ha in 2012 (Fig. 2(b) and (d)). Both maize and cotton farmers also earned money, albeit less than wheat farmers. For example, in 2009, maize farmers earned 62 yuan per ha and cotton farmers earned 60 ((b) in Fig. 3; (b) in Fig. 4). As the subsidy is closely related to the use of electricity for groundwater irrigation, wheat farmers used more irrigation and thus earned more money from the reform, possibly because wheat is irrigated more frequently.

\subsection{Some issues relevant to the sustainable implementation and extension of the reform}

As stated above, the pilot reform significantly reduced the groundwater application rate for irrigating major crops and did not result in income lose for most farmers. However, it is interesting that this pilot reform has not been extended to other regions, even after more than 10 years of observation. It is also important that both central and local government policymakers are concerned about this issue. What are the reasons for this situation?

\footnotetext{
${ }^{6}$ The plot samples from 2012 of the three crops had reduced since 2009, because some households did not plant the same crop in the two sample plots in 2012.

${ }^{7}$ Instead of looking at crops separately, it makes more sense to look at the total crop income from all crops together, which more accurately reflects how the reform affects the total crop income of a household. However, we only selected two plots from each household to collect information on the production input and output. In addition, the major crops planted in these two plots were wheat, maize, and cotton; plots planted with other crops were not included in the survey. Therefore, we had no way to estimate income from all crops at the household level.
}

In the following section we will discuss some of the possible reasons constraining the extension of the pilot reform.

\subsubsection{Representatives of villages that participated in the pilot reform}

Our survey results revealed that the villages that participated in the pilot reform shared several socioeconomic characteristics: (1) they mainly depended on groundwater for irrigation; (2) they mainly used deep tubewells to provide groundwater for irrigation; and (3) these tubewells were mainly managed by village leaders. The first characteristic is common in many villages in northern China (Wang et al., 2009); however, the second and third are not part of the overall picture of this area. Based on a large field survey of northern China, Wang et al. (2006, 2009) found that although there was an obvious increase in the number of deep tubewells in many villages, shallow tubewells were still a major source of groundwater for farm irrigation. In addition, most tubewells are paid for and managed by farmers, not village leaders. Because most villages in northern China have shallow and deep tubewells, they tend to have more tubewells than the pilot villages did. Therefore, if the reform is to be extended to other regions in northern China, it may prove to be more complicated in the implementation, and the government would be better off selecting other villages with different socioeconomic characteristics for the experiment.

\subsubsection{The amount, form, and sources of subsidies for the reform}

The provision of subsidies is an important factor in encouraging village leaders and farmers to participate in the reform. However, even when most farmers can earn money by receiving a subsidy, why do some villages still choose to withdraw from the reform? Comparing the amounts offered in the pilot reform with government agricultural subsidies may provide an answer. In China, the government provided a total of 166.8 billion yuan in agricultural subsidies to farmers, including grain, seed, machinery, and aggregate input subsidies (Huang et al., 2013). In 2012, 0.11 billion ha were planted with grain, meaning that farmers received agricultural subsidies of 1516 yuan per ha; this number is much higher than the subsidies disbursed through the pilot reform. In the pilot reform, wheat farmers received on average a subsidy of 181 yuan per ha (11\% of the agricultural subsidy) and earned 204 yuan per ha (13\% of the agricultural subsidy) (Fig. 2). In other words, the value of the reform subsidies provided little incentive for farmers to participate. Therefore, if the government wants to encourage more farmers to take part in the reform and implement price reforms in the future, designating a suitable amount as a subsidy will be an important factor to their success.

In addition to the value, the type of subsidy also needs to be considered carefully. Our survey found that subsidy amount is closely linked to electricity use, as it is measured by the units of electricity used (yuan $/ \mathrm{kW}$ ). This means that if a village uses more electricity (and thus more groundwater), they receive more subsidies. However, the purpose of the reform is to reduce the total amount of electricity used, thereby reducing the exploitation of groundwater. Therefore, based on the present subsidy, and since the subsidy is granted at the village level, such a subsidy has reduced the incentive of village leaders to encourage farmers to reduce their irrigation rate. As the subsidy has been allocated to all farmers equally, it will not influence their irrigation behavior. If the government would like to use subsidies to reduce the groundwater application rate (not just to encourage farmers to participate in the reform), it would be better to redesign the reform so as not to link the subsidies to electricity use; and if there is a link, it should be a negative one, not a positive one such as at present. Another possible way is to provide subsidies of a uniform value if the villages or farmers can reduce their reliance on groundwater to a certain degree. In any case, there should be more choices 
(a) Benefits or losses due to pilot price reform if no subsidy for wheat farmers in 2009 (yuan/ha)

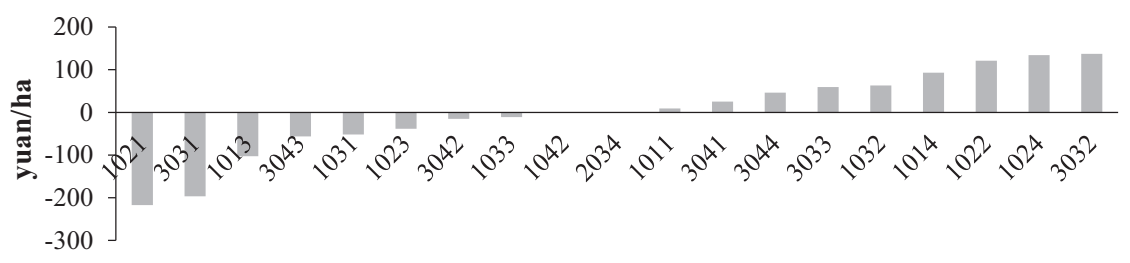

Household code

(b) Benefits or losses due to pilot price reform if having subsidy for wheat farmers in 2009 (yuan/ha)

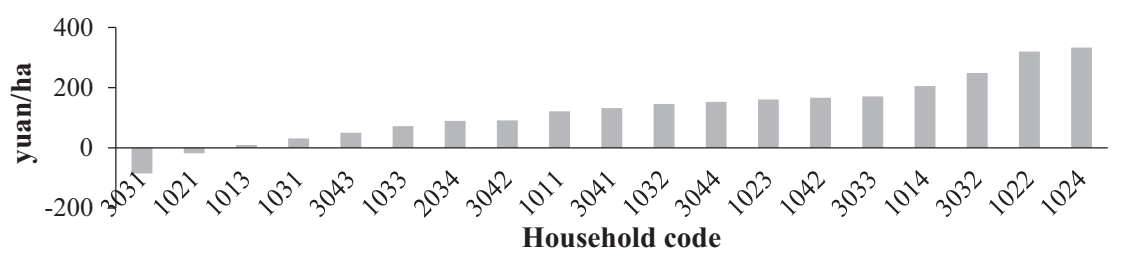

(c) Benefits or losses due to pilot price reform if no subsidy for wheat farmers in 2012 (yuan/ha)

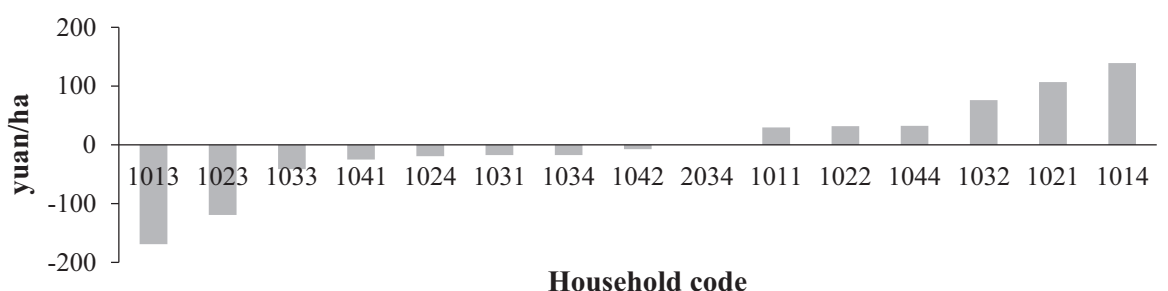

(d) Benefits or losses due to pilot price reform if having subsidy for wheat farmers in 2012 (yuan/ha)

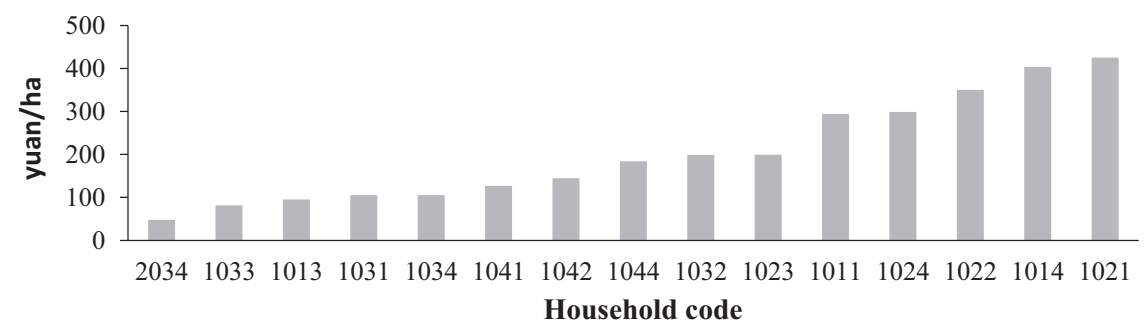

Fig. 2. Benefits and losses due to pilot price reform for wheat farmers in pilot reformed villages.

with regard to subsidy design, so that the pilot reform can test the effectiveness of various forms of subsidy.

The final issue is the source of the subsidies. At present, they are provided through special Water Saving Society project funding. However, such a source is not sustainable, as the projects could end. In the future, if the government wants to implement irrigation price reform and realize the win-win goal of increasing irrigation efficiency while maintaining farmers' income, it should establish a single formal fund source to provide the subsidies. In fact, the government has already implemented such a subsidy policy for agricultural production. Those designing the subsidy policy can also learn from the experience of the agricultural subsidies. Another important source for the irrigation price reform subsidies is the water resource fees collected in China. In 2008, China's central government issued a regulation on water resource fees; based on this, the fees should be allocated to water-saving measures.
Therefore, the government could use these collected water resource fees as an important financial source for subsidies in a future irrigation price reform effort.

\subsubsection{Reform design and monitoring issues}

There is still room to further improve the reform's design and implementation. This pilot reform was designed by policymakers of the Taocheng WAB, whose major advantage is their rich experience in implementing water policies and thorough understanding of local physical and socioeconomic characteristics. Due to this advantage, the pilot reform was implemented well and achieved the win-win policy reform goal. Even so, if policymakers' experience can be combined with research studies (such as a study of water demand and price elasticity), the reform could be better designed and possibly extended to other regions. Furthermore, any future pilot reform must also further strengthen the 
(a) Benefits or losses due to pilot price reform if no subsidy for maize farmers in 2009 (yuan/ha)

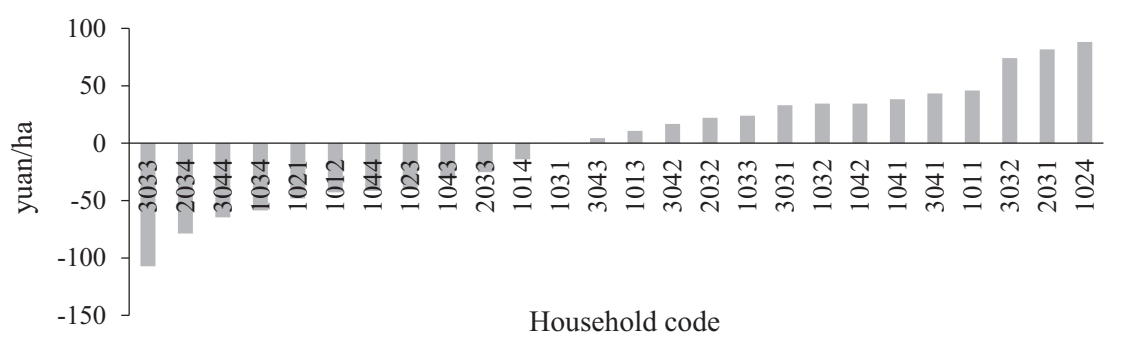

(b) Benefits or losses due to pilot price reform if having subsidy for maize farmers in 2009 (yuan/ha)

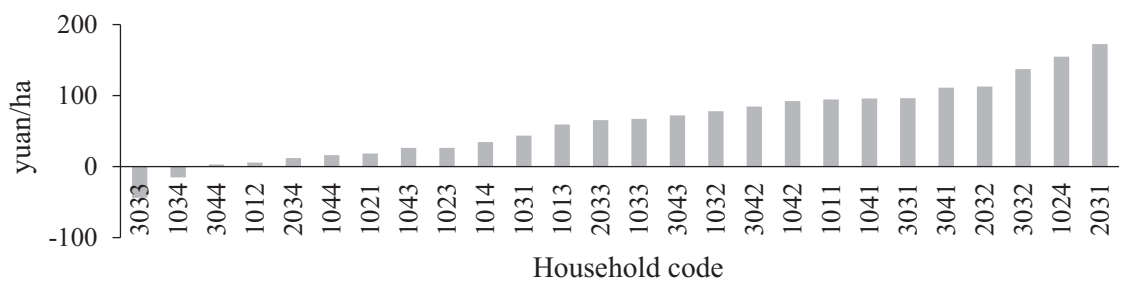

(c) Benefits or losses due to pilot price reform if no subsidy for maize farmers in 2011 (yuan/ha)

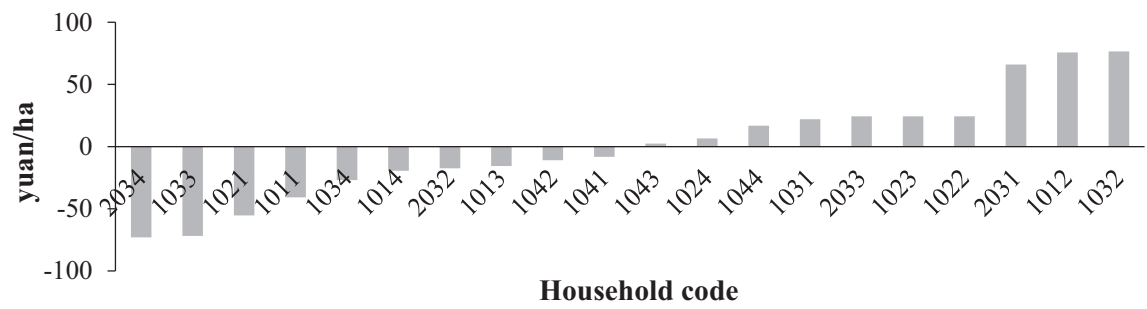

(d) Benefits or losses due to pilot price reform if having subsidy for maize farmers in 2012 (yuan/ha)

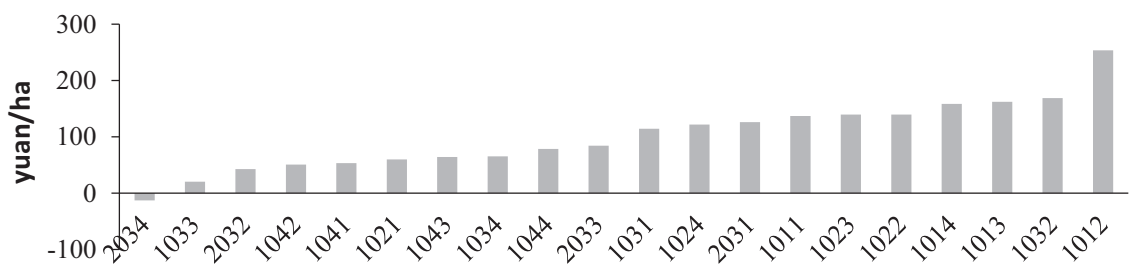

Household code

Fig. 3. Benefits and losses due to pilot price reform for maize farmers in pilot reformed villages.

monitoring of the implementation. As we found in our survey, not all pilot villages implemented the reform, and some did so only nominally.

\subsubsection{Extension to surface irrigation price reform and linkage to water} rights reform

Not only does the groundwater irrigation price need to be reformed, the price of surface water irrigation must be as well. The experiences and lessons of the pilot reform for groundwater irrigation in Taocheng provided good evidence for designing a surface water irrigation price reform. However, implementing such a reform would be more difficult than it was for groundwater. One major difficulty is the poor measurement of irrigation practices. Although groundwater irrigation is also difficult to measure, tubewells have electricity meters that can be used to ascertain the groundwater application rate. However, though it is hard to identify a means of measuring each farmer's use of surface water for irrigation, it is possible to do so for small groups. Presently, most villages in China measure the total amount of surface water used for irrigation at the village level (and even by farmer group in some villages). If the government can invest in such measurement facilities in villages, it will be possible to find a way to measure how much surface irrigation is used by small groups of famers. If so, surface water irrigation price reform could use a similar mechanism to reform prices. Of course, more pilot experiments and studies must be undertaken to determine how to implement such a reform.

The final step relevant to offering incentives to village leaders and farmers to participate in the price reform is to ask them why 
(a) Benefits or losses due to pilot price reform if no subsidy for cotton farmers in 2009

(yuan/ha)

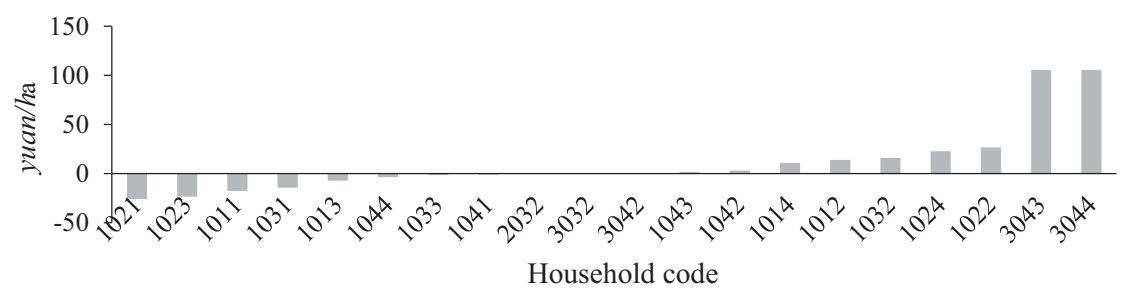

(b) Benefits or losses due to pilot price reform if having subsidy for cotton farmers in 2009 (yuan/ha)

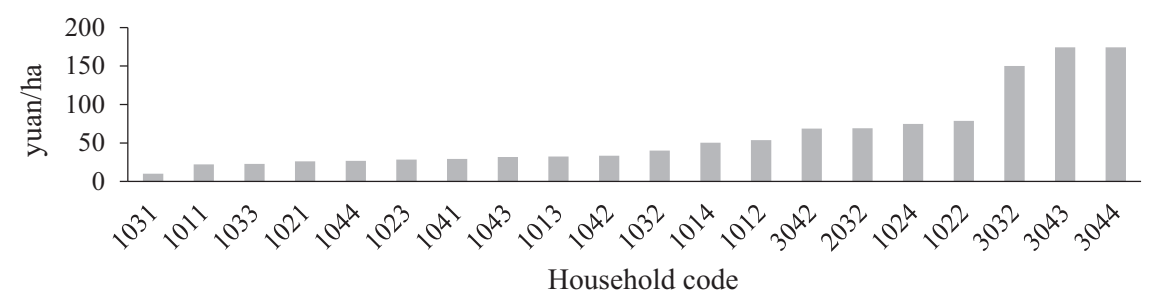

(c) Benefits or losses due to pilot price reform if no subsidy for cotton farmers in 2012 (yuan/ha)

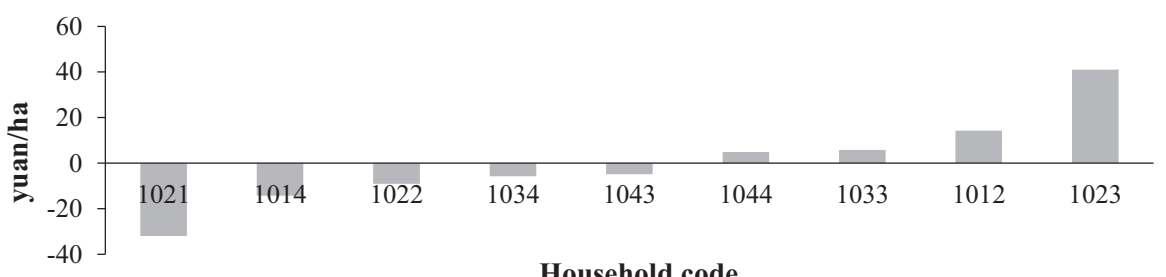

(d) Benefits or losses due to pilot price reform if having subsidy for cotton farmers in 2012 (yuan/ha)

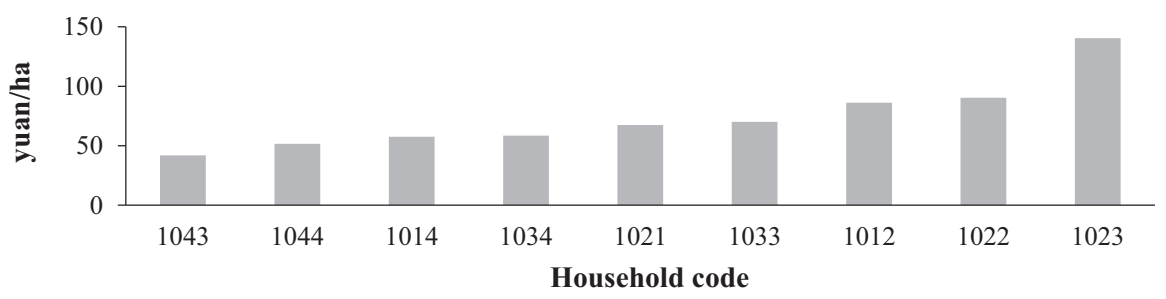

Fig. 4. Benefits and losses due to pilot price reform for cotton farmers in pilot reformed villages.

they would like to reduce groundwater irrigation. As discussed above, receiving a government subsidy is an important factor in encouraging village leaders and farmers to implement the reform. However, if the water saved by reducing irrigation could be sold on the open market, farmers would have a greater and more sustainable incentive to reduce their reliance on irrigation. That is, if irrigation price reform can be supported by reforming water rights and water markets at the same time, it will be easier to realize a win-win strategy. Although water rights and water market reform have been thoroughly addressed by the government, the proper design and implementation of such a reform is still a difficult issue that requires more study.

\section{Conclusion and policy implications}

The overall goal of this paper was to evaluate the effectiveness of a pilot irrigation price reform in realizing a win-win reform strategy to reduce irrigation while maintaining or even increasing farmers' income. In order to do so, we conducted a two-round field survey in Taocheng District, Hebei Province in 2009 and 2012. Based on this survey, the key mechanism of the pilot reform was that farmers received similar returns (including reallocated increased irrigation fees and a government subsidy) by area; however, they paid different irrigation fees by area, because their groundwater application rate varied. The difference between irrigation fees paid and return was treated as an incentive for farmers to reduce their use of groundwater for irrigation. Although $70 \%$ of the pilot villages implemented the reform, $30 \%$ did so only nominally in 2009. By 2012, the percentage of villages that were implementing the reform had dropped to $50 \%$, as some withdrew from the project. In villages that implemented the reform, the local farmers' irrigation fees increased by more than one-third in nominal terms and about one-fifth in real terms. The government subsidy was equivalent to approximately $35 \%$ of the increased 
irrigation fee, and there was no obvious change in the value of the subsidy between 2009 and 2012 .

The econometric results showed that implementing the reform could significantly reduce the groundwater application rate for irrigating wheat and cotton. If the villages implemented the reform, local farmers' groundwater application rate for irrigating wheat and cotton could decrease by $21 \%$ each. However, the reform had no significant impact on the groundwater application rate for irrigating maize. Further analysis indicated that if groundwater irrigation fees increased by 1 yuan $/ \mathrm{kW}$ (an increase of approximately $100 \%$ over the present fee), the groundwater application rate for irrigation could be reduced by $50 \%$ for wheat and $59 \%$ for cotton. If no subsidies are granted, roughly half of the region's farmers would lose money due to the reform. However, most farmers who receive subsidies could earn money in villages that implement the reform, and wheat farmers tend to earn more than maize or cotton farmers. Our data also indicated that the percentage of irrigation fee over total material cost is $22 \%$ for wheat, $14 \%$ for cotton, and $9 \%$ for maize. Therefore, reducing the groundwater application rate for irrigating wheat and cotton is more important than for maize. Due to data limitations, this study did not include an assessment of the hydrological impacts of the reform; this important issue will need to be explored in the future.

Despite the success of the pilot reform in Taocheng, it has not been extended to other regions. If the following issues are resolved, it would be possible for more regions to realize a win-win price reform strategy:

(i) Select more representative villages that have both shallow and deep tubewells, and both collective and individual managers.

(ii) Increase the value of the subsidies to a uniformly high level that will fully encourage farmers to support the reform (the subsidy given out in the pilot reform was only $13 \%$ of the value of the government's agricultural subsidy).

(iii) The subsidy must not be positively linked to electricity use (or groundwater application rate); if there is a link, it should be a negative one. Other choices for subsidy type (such as a constant value) should also be considered carefully.

(iv) One formal fund source should be established, as depending on the pilot project funds to provide the subsidies is not sustainable.

(v) Scholars need to conduct more empirical studies to support government pilot reform programs.

(vi) If the government can invest in measurement facilities for villages, it will be possible to apply a similar mechanism to conduct a pilot reform program for surface irrigation prices.

(vii) If irrigation price reform can be supported by reforming water rights and water markets, it will be easier to realize a win-win strategy in the long term.

\section{Acknowledgements}

We acknowledge the financial support of the National Natural Sciences Foundation in China (71161140351 and 91325302), Ministry of Science and Technology in China (2012CB955700), and Chinese Academy of Sciences (Y02015004 and KSZD-EW-Z-021-1).

\section{Appendix A}

See Tables A-C.
Table A

Descriptive statistics of variables for wheat models

\begin{tabular}{|c|c|c|c|c|}
\hline & Mean & $\begin{array}{l}\text { Std. } \\
\text { Dev. }\end{array}$ & Min & Max \\
\hline $\begin{array}{l}\text { Irrigation application rate of } \\
\text { groundwater e }\left(\mathrm{m}^{3} / \mathrm{ha}\right)\end{array}$ & 2805 & 1349 & 420 & 12150 \\
\hline Pilot reformed villages $(1=$ yes; $0=$ no $)$ & 0.25 & 0.43 & 0.00 & 1.00 \\
\hline $\begin{array}{l}\text { Pilot non-reformed villages }(1=\text { yes; } \\
\quad 0=\text { no })\end{array}$ & 0.12 & 0.33 & 0.00 & 1.00 \\
\hline Change of water price (yuan/kW) & 0.06 & 0.12 & -0.31 & 0.33 \\
\hline Surface water use $\left(\mathrm{m}^{3} / \mathrm{ha}\right)$ & 185.74 & 570.69 & 0.00 & 4000.00 \\
\hline $\begin{array}{l}\text { Whether water is scarce ( } 1=\text { yes; } \\
\quad 0=\text { no) }\end{array}$ & 0.39 & 0.49 & 0.00 & 1.00 \\
\hline Age of household head (years) & 52.00 & 9.34 & 29.00 & 84.00 \\
\hline Education of household head (years) & 7.74 & 2.35 & 0.00 & 12.00 \\
\hline Share of off-farm labors & 0.15 & 0.25 & 0.00 & 1.00 \\
\hline Farm size (ha) & 0.20 & 0.09 & 0.05 & 0.53 \\
\hline Loam land $(1=$ yes; $0=$ no $)$ & 0.43 & 0.50 & 0.00 & 1.00 \\
\hline Clay land $(1=$ yes; $0=$ no $)$ & 0.27 & 0.45 & 0.00 & 1.00 \\
\hline Distance from plot to tubewell $(\mathrm{km})$ & 0.24 & 0.21 & 0.00 & 1.00 \\
\hline Share of ground pipe & 0.82 & 0.28 & 0.00 & 1.00 \\
\hline Share of surface pipe & 0.16 & 0.27 & 0.00 & 1.00 \\
\hline
\end{tabular}

Note: The observation number is 161 .

Table B

Descriptive statistics of variables for maize models

\begin{tabular}{|c|c|c|c|c|}
\hline & Mean & $\begin{array}{l}\text { Std. } \\
\text { Dev. }\end{array}$ & Min & Max \\
\hline $\begin{array}{l}\text { Irrigation application rate of } \\
\text { groundwater }\left(\mathrm{m}^{3} / \mathrm{ha}\right)\end{array}$ & 1459 & 723 & 315 & 4500 \\
\hline Pilot reformed villages $(1=$ yes; $0=$ no $)$ & 0.31 & 0.46 & 0.00 & 1.00 \\
\hline $\begin{array}{l}\text { Pilot non-reformed villages }(1=\text { yes; } \\
\quad 0=\text { no })\end{array}$ & 0.14 & 0.35 & 0.00 & 1.00 \\
\hline Change of water price (yuan/kW) & 0.07 & 0.13 & -0.31 & 0.33 \\
\hline Surface water use $\left(\mathrm{m}^{3} / \mathrm{ha}\right)$ & 28.98 & 155.90 & 0.00 & 1371.43 \\
\hline $\begin{array}{l}\text { Whether water is scarce }(1=\text { yes; } \\
\qquad 0=\text { no) }\end{array}$ & 0.35 & 0.48 & 0.00 & 1.00 \\
\hline Age of household head (years) & 51.47 & 8.55 & 29.00 & 71.00 \\
\hline Education of household head (years) & 7.91 & 2.23 & 2.00 & 12.00 \\
\hline Share of off-farm labors & 0.14 & 0.24 & 0.00 & 1.00 \\
\hline Farm size (ha) & 0.20 & 0.09 & 0.05 & 0.53 \\
\hline Loam land $(1=$ yes; $0=$ no $)$ & 0.37 & 0.49 & 0.00 & 1.00 \\
\hline Clay land $(1=$ yes; $0=$ no $)$ & 0.32 & 0.47 & 0.00 & 1.00 \\
\hline Distance from plot to tubewell $(\mathrm{km})$ & 0.25 & 0.24 & 0.00 & 2.00 \\
\hline Share of ground pipe & 0.83 & 0.28 & 0.00 & 1.00 \\
\hline Share of surface pipe & 0.15 & 0.26 & 0.00 & 1.00 \\
\hline
\end{tabular}

Note: The observation number is 182 .

Table C

Descriptive statistics of variables for cotton models

\begin{tabular}{|c|c|c|c|c|}
\hline & Mean & $\begin{array}{l}\text { Std. } \\
\text { Dev. }\end{array}$ & Min & Max \\
\hline $\begin{array}{l}\text { Irrigation application rate of } \\
\text { groundwater }\left(\mathrm{m}^{3} / \mathrm{ha}\right)\end{array}$ & 1142 & 472 & 525 & 3750 \\
\hline Pilot reformed villages $(1=$ yes; $0=$ no $)$ & 0.34 & 0.48 & 0.00 & 1.00 \\
\hline $\begin{array}{l}\text { Pilot non-reformed villages }(1=\text { yes; } \\
\quad 0=\text { no })\end{array}$ & 0.14 & 0.35 & 0.00 & 1.00 \\
\hline Change of water price (yuan/kW) & 0.08 & 0.12 & -0.31 & 0.30 \\
\hline Surface water use $\left(\mathrm{m}^{3} / \mathrm{ha}\right)$ & 33.88 & 312.38 & 0.00 & 2880.00 \\
\hline $\begin{array}{l}\text { Whether water is scarce ( } 1 \text { = yes; } \\
\quad 0=\text { no) }\end{array}$ & 0.48 & 0.50 & 0.00 & 1.00 \\
\hline Age of household head (years) & 50.45 & 7.58 & 31.00 & 67.00 \\
\hline Education of household head (years) & 7.73 & 2.22 & 0.00 & 12.00 \\
\hline Share of off-farm labors & 0.23 & 0.27 & 0.00 & 1.00 \\
\hline Farm size (ha) & 0.19 & 0.11 & 0.03 & 0.60 \\
\hline Loam land $(1=$ yes; $0=$ no $)$ & 0.28 & 0.45 & 0.00 & 1.00 \\
\hline Clay land $(1=$ yes; $0=$ no $)$ & 0.36 & 0.48 & 0.00 & 1.00 \\
\hline Distance from plot to tubewell $(\mathrm{km})$ & 0.31 & 0.30 & 0.00 & 1.50 \\
\hline Share of ground pipe & 0.80 & 0.27 & 0.00 & 1.00 \\
\hline Share of surface pipe & 0.19 & 0.26 & 0.00 & 1.00 \\
\hline
\end{tabular}

Note: The observation number is 85 . 


\section{References}

Blanke, A., Rozelle, S., Lohmar, B., Wang, J., Huang, J., 2007. Water saving technology and saving water in China. Agric. Water Manage. 87, 139-150.

Chang, B., Liu, M., 2010. Study on water saving effect of "Increase Water Price and Provide Subsidy" reform. China Water Conserv. 7, 41-44.

Chen, L., 2009. Implementing the strictest water management institution to ensure sustainable development of socio-economy. China Water Conserv. 5, 9-17.

Chen, S., Wang, Y., Zhu, T., 2014. Exploring China's farm-level water-saving mechanisms: analysis of experiment conducted in Taocheng District, Hebei Province. Water 6, 547-563.

Dinar, A., Mody, J., 2004. Irrigation water management policies: allocation and pricing principles and implementation experience. Nat. Resour. Forum 28 (2), $112-122$.

Dinar, A., Saleth, R.M., 2005. Issues in water pricing reforms: from getting correct prices to setting appropriate institutions. In: Folmer, H., Tietenbirg, T. (Eds.), The International Yearbook of Environmental and Resource Economics 2005/2006. Edward Elgar, Cheltenham, UK.

ECSNCCA (Edition Committee of the Second National Climate Change Assessment), 2011. Second National Climate Change Assessment Report. Science Press, Beijing.

Gomez-Limon, J.A., Riesgo, L., 2004. Irrigation water pricing: differential impacts on irrigated farms. Agric. Econ. 31, 47-66.

Hellegers, P.G.J., Perry, C.J., 2006. Can irrigation water use be guided by market forces? Theory and practice. Int. J. Water Resour. Dev. 2 (1), 79-86.

Huang, J., Wang, X., Rozelle, S., 2013. The subsidization of farming households in China's agriculture. Food Policy 41, 124-132.

Huang, Q., Rozelle, S., Howitt, R., Wang, J., Huang, J., 2010. Irrigation water demand and implications for water pricing policy in rural China. Environ. Dev. Econ. 15, 293-319.

Li, Q., 2009. The new mechanism of "Increase Water Price and Provide Subsidy" in Taocheng District adds vitality for agricultural water saving: survey on the new model of water saving in Taocheng District, Hengshui City. Hebei Water Conserv. 5, 4-5.

Liu, Y., Wang, J., Li, Y., Zhang, L., 2011. Adoption of water saving technologies and determinants. Nat. Resour. Bull. 26 (6), 932-942.

Mejias, P., Varela-Ortega, C., Flichman, G., 2004. Integrating agricultural policies and water policies under water supply and climate uncertainty. Water Resour. Res. 40, W07S03. http://dx.doi.org/10.1029/2004WR002877.
Moore, M.R., Gollehon, N.R., Carey, M.B., 1994. Multicrop production decisions in western irrigated agriculture: the role of water price. Am. J. Agric. Econ. 76 (4), 859-874.

MWR (Ministry of Water Resources), 2002. Water Resources Bulletin, Ministry of Water Resources.

MWR (Ministry of Water Resources), 2014. Water Resources Bulletin, Ministry of Water Resources Available at <http://www.tlmicronano.com/index.php? $\mathrm{m}=$ content $\& \mathrm{c}=$ index\&a=show $\&$ catid $=17 \& \mathrm{id}=794>$.

Ogg, C.W., Gollehon, N.R., 1989. Western irrigation response to pumping cost: a water demand analysis using climatic regions. Water Resour. Res. 25 (5), $767-$ 773.

Schoengold, K., Sunding, D.L., Georgina, M., 2006. Price elasticity reconsidered: panel estimation of an agricultural water demand function. Water Resour. Res. 42 (9).

Wang, J., 2012. Water management problem in establishing resource saving society. Bull. Chin. Acad. Sci. 27 (4), 447-454.

Wang, J., Huang, J., Huang, Q., Rozelle, S., 2006. Privatization of tubewells in North China: determinants and impacts on irrigated Area, productivity and the water table. Hydrogeol. J. 14, 275-285.

Wang, J., Huang, J., Rozelle, S., Huang, Q., Zhang, L., 2009. Understanding the water crisis in northern China: what government and farmers are doing? Int. J. Water Resour. Dev. 25 (1), 141-158.

Wang, J., Huang, J., Yan, T., 2013. Impacts of climate change on water and agricultural production in ten large river basins in China. J. Integr. Agric. 12 (7), 1267-1278.

Water Resources Bureau of Hengshui City (WRBHC), 2012. The Situation of Water Resources in Hengshui Available at <http://www.hsswj.gov.cn/ch1882/index. shtml>.

Water Resources Bureau of Taocheng District (WRBTD), 2012. Taocheng WaterSaving Experience Gets National Reputation (in Chinese). Available at <http:// hs.hebnews.cn/2012-05/23/content_2702309.htm> (accessed on 15 October 2013).

Wooldridge, J.M., 2002. Econometric Analysis of Cross Section and Panel Data. MIT Press, Cambridge.

Yan, T., Wang, J., Huang, J., 2015. Urbanization, agricultural water use, and regional and national crop production in China. Ecol. Model. 318, 226-235. 